\title{
Model of Perception and Critical Language Style of Academic Community at University of Bengkulu During Coronavirus Disease (COVID) 19 Epidemic to Realize the Freedom of Learning
}

\author{
Dian Eka Chandra Wardhana ${ }^{1, *}$, Dewi Kusumaningsih ${ }^{2}$ \\ Anggun Citra Sari Dewi ${ }^{3}$
}

\author{
${ }^{1}$ Indonesian Language Department, FKIP University of Bengkulu, Bengkulu, Indonesia 38371A \\ ${ }^{2}$ Veteran Bangun Nusantara University, Sukoharjo, Jawa Tengah, Indonesia 57521 \\ ${ }^{3}$ English Department, FKIP University of Bengkulu, Bengkulu, Indonesia 38371A \\ *Corresponding author Email: dec.wardhana@unib.ac.id
}

\begin{abstract}
The multifaser crisis has an impact on education in Indonesia, this is due to the coronavirus disease 19 (COVID-19) epidemic. However, the innovation and creativity of the academic community at Bengkulu University are extraordinary. The purpose of this study was to illustrate the model of language and the perceptions of the academic community in participating to overcome the crisis as a way to realize the independept learning at university. This qualitative research involves all of the academic community at the Bengkulu University. Data collection used was communication ethnography techniques by recording, participatory and non-participatory reading, questionnaires, and field notes. The data analysis steps were (1)transcripting, (2)reducting, and (3)grouping various styles/models of subject language, then (4)formulating the data with applications. The results showed that the subject of this study has the critical, innovative, and creative language models of the independent learning at the university. In conclusion, the academic community at the Bengkulu University plays an active role and can be a model to overcome the COVID-19 epidemic crisis to realize the freedom of learning.
\end{abstract}

Keywords: perception, critical language style, coronavirus (COVID) 19 epidemic, academic community

\section{INTRODUCTION}

Human characteristics of the $21^{\text {st }}$ century are categorized as 4C (creative, critical, collaborative and communicative) [1], and always offer solutions to problems [2]. Since late of 2019 - early 2020 virus disease 19 has infected 110 countries and on March $11^{\text {th }}$ $2020 \mathrm{WHO}$ declared it as a pandemic. According to Jokowi [3], the President of Indonesia, Covid-19 has attacked 255 countries including Indonesia. This fact is not only a public health crisis, but a multifaser crisis, because it has a negative impact on education [4]. Teachers and students cannot meet face to face at school so the access of information is determined by the internet, despite the fact that there are still barriers about the internet signal.

Another fact that developed at this time was that the Minister of Education seems to have the opportunity to realize his dream of liberating schools and campuses through Circular Letter (SE) no. 36962 / MPK.H / HK / 2020 which provides 5 large pages for home study. The ideals of realizing an independent campus have also been initiated, and are targeting Higher Education [4]. There are four independent learning policies and one of them is "Students are free to learn a maximum of 3 semesters outside the Study Program" so it will give them new learning experiences, engage in interesting activities, challenge, and even "endanger" [5], in order to think, create, imagine and express their interests.

This system was known as major and minor skills in Indonesian Language Education Study Program of Faculty of Teacher Training and Education (FKIP), Bengkulu University (UNIB) and Malang State University (UM). The competency-based curriculum (KKNI) provides opportunities for students to take courses in their study programs (major) in order to have major skills, as well as to take courses in one of the minor fields (in the same study program) as a complementary skills or to take courses in other study programs as supporting skills.

The phenomenon of the Independent Campus allows students and lecturers to migrate between fields of science. So it requires mutually agreed rules and 
cooperation facilities that require government intervention to ensure the sustainability of an independent campus [6]. The lecturer as a facilitator and friend for students to be free to learn and seek experience on the independent campus, is ideally a way for lecturers to build expertise and improve the quality of research and service to strengthen their expertise [7]. The realization of this thought for the Indonesian Language Education Study Program is expected to facilitate students to be able to be free on language and literature for free of learning [5].

Based on that phenomenon, a problem arises: "How was the critical language models and the perceptions of academic community in FKIP UNIB in realizing the independent learning model during covid-19 pandemic era". Along with this problem, the specific purpose of this study was to find out the perception model and language style of lecturers of the Department of Language and Arts Education, as well as stakeholders in FKIP and faculties that students like at several universities in the West Coast of Sumatra in welcoming independent campus activities.

The urgency of this paper is preceded by an understanding that various memorandums of understanding between UNIB and various Universities with A category has been designed and signed $(80 \%$ are in the form of MOA), but the realization of the implementation is still stagnant. Various MOAs were formulated with the aim of increasing competence and broading insights of the UNIB academic community, as envisioned by Unib's Vision and Mission so that in the eruption era 04.0 [8] it could be worldwide. The era of significant changes in the world of education from the descriptive era to the era of critical, creative, collaborative, innovative, and communicative [9], which began with the introduction of the concept of an independent campus in Unib, although the simple concept of the perception of an independent campus in the Unib will be shown in the new curriculum designed by Study Program.

The innovation targeted by this paper is the formulation of the 21 st century learning model. The learning model innovation that is intended refers to the theory of findings [10] especially in formulating Learning activities in the Independent Campus during the covid19 pandemic period. This model has been formulated by 2 previous research reports conducted by [6] and [11]. Both of these studies found that there was a tendency that learning in tertiary institutions was transdisciplinary. Furthermore, other innovations are about the use of technology and language models of stakeholders, lecturers and employees on Campus. This has a profound impact on the management of life and human life, especially the improvement of new competencies that must be possessed by lecturers, students and related officials at UNIB, by not neglecting local traditions that have been institutionalized for years in the community. Those three models are new values that are rooted in the local traditions of the community which already inherent in the community [12].

\section{METHOD}

This research was conducted using qualitative methods with communication ethography techniques [13] involving all lecturers in the Department of Language and Arts Education FKIP UNIB. This research is in the form of styles and models of language set that were done by research subjects when interacting and transacting to develop an independent campus work program, including their perceptions. The research data were in the form of speech that reflects the perception and critical language style of the academic community at the UNIB during Covid-9 epidemic to realize the independent learning. Data was collected by recording (using recording tool on Samsung A8), participatory and non-participatory reading, questionnaires (consists of 10 open questions and 10 multiple choice questions as a guide when interviewing research subjects) and also descriptive and reflective field notes. The subjects of this study were all the lecturers, stakeholders and staff of independent campus. Interview activities with research subjects were conducted to explore things that have not been obtained, through observation activities, view recordings of the independent campus of Youtube (both formal and informal activities), as well as filling out a questionnaire.

There were five experts who has been involved for the questionnaire test. Expert test data was processed using the Delphi technique and inter-subjectivity tests. The result is the $r 11=0.767$ was greater than 0.70 . Thus the formulated instruments can be trusted. This valid and reliable questionnaire was used to collect data.. After the data were collected, data analysis was carried out. Data analysis was conducted by (1) transcripting the recorded results, (2) reducting data, (3) collecting all data (field notes, interviews, questionnaires), (4) grouping various styles/models of language used by subjects when interacting, transacting, and when perceiving by using certain indicators, (5) formulating the subject's style/model when realizing the Merdeka Belajar campus with the NVIVO application. A qualitative analysis model with the NVIVO application has been carried out by 400,000 other researchers in 150 countries [14].

\section{RESULT AND FINDING}

The results' review of this study began with opening a conversation activity between researchers and subjects through a private chat conducted with WA. Then the conversation between the Subject and the researcher opened with the following application; (1) open the conversation on the respondent's chat. (2) click the 3 dots (...) at the top right, after exiting the menu, click OTHER options. (3) select EXPORT CHAT, (4) click INCLUDE MEDIA, (5) click e-mail, then enter the email to be addressed.

The research subjects consisted of 7 subjects, 3 professors and 2 lecturers, and 2 WAG groups (1. lecturers and the study program's coordinators and 2 . the study program's coordinators and Faculty and University's administrators) that coordinated every day. The results of the conversation were transcribed in 
text form with the applications that commonly used by the court to transcribe a conversation, then it was analyzed with the NVIVO application. In addition to this, the research data was also transcribed from the results of the recording, which was conducted by participatory and non-participatory reading, as well as filling out questionnaires and field notes. Participatory reading activities needed to be done because these stakeholders are members of the WA group of academic management and coordination. Content of these groups were often discussed SE both from the ministry and rector. There were also circulated a lot of $\mathrm{SE}$, videos and responses from group members within the WA group of the faculty's stakeholders. Group members often uploaded newspaper texts and other texts circulating on social media related to research content. All data in the form of non-conversation data were analyzed with the NVIVO application.
Furthermore, the data for this study was also taken from texts (newspapers) written by the subjects as well as from several videos uploaded to respond to the Minister of Education and Culture's policies. In addition to this, several SE which had been used as a policy to act on several activities at UNIB campus became valid data. But the display of analytical data from the NVIVO application is very complex and long. Thus the results of the analysis must be addressed one by one so that the appearance of the analysis results submitted by the application can be comprehensively understood and meet the template standards desired by AMCCA 2020. Moreover, the results of the analysis with the NVIVO application was showed in this article. Contribution of conversation results with the intended research subject can be illustrated in table 1 to form a tree diagram by the NVIVO application. The subject names on this article are written with the initials only.

Tabel 1: Contribution of Chat Conversations with Research Subjects

\begin{tabular}{|c|c|c|}
\hline $\begin{array}{c}\text { WhatsApp Chat with: } \\
\text { (Initial) }\end{array}$ & References & Coverage \\
\hline J E & 5 & $1,70 \%$ \\
\hline JUM & 2 & $0,69 \%$ \\
\hline K A & 14 & $0,69 \%$ \\
\hline PFU & 2 & $0,09 \%$ \\
\hline PP & 8 & $1,50 \%$ \\
\hline Sur & 5 & $1,09 \%$ \\
\hline Syah & 10 & $1,58 \%$ \\
\hline
\end{tabular}

Based on the recorded data in the NVIVO application, it appears that the perception of the independent campus of each subject was different. JE's contribution seems the most significant because the perception possessed by $\mathbf{J} \mathrm{E}$ was the perception that is in accordance with the independent campus guidebook. This is due to JE's mentality and position as the general secretary of IKAPROBSI (Association of Indonesian Language Study Programs throughout Indonesia). This was emphasized by the critical language style used to explain the perception. Their critical language style that was influenced by the cooperative maxims (Cooperative Principle), to respond researcher's speech with politeness with the typical mode of peer communication, and formal language. These style of language is critically conveyed in response to the speech partner's so that the desired data can be collected (see figure 1).

Examples of critical speech in order to perceive the intended independent campus model are; (1) learning model implemented by online media, (2) independent learning is still a conceptual level and an idea of young generation, 3) the implementation of these activities is not an easy job, so just follow it as an insight, (4) students can study across-campuses, but should have think about the costs, the sectoral egoism and the ability of the students. Critical speech was used to respond to statement (1) masih WFH ya...wah mahasiswa merdeka, dosen sebagai penggeraknya, jadi merdeka juga. Therefore it was responded critically, that learning should be carried out online. Likewise speech (2) which was critically used to respond to a conversation about the implementation of an independent campus in the university. Then, the third critical speech appeared to answer the phenomenon about the possibility of students taking lectures acrosscampuses. This statement appears due to the phenomenon of students who takes minor courses in the study program and in FKIP UNIB students have been conducting lectures accross universities. But we need to consider about some factors such as local selfishness, academic competencies and social competencies specifically possessed by the students. In addition, the overall competencies of students should be explored earlier to support this policy.

A detailed description about the perception of FKIP UNIB academic's community and their critical language style are shown in diagram 1 . This diagram showed the results of the Text Search Query - Results Preview analysis, perception of the concept of the term "merdeka" used in the context of independent learning on campus. 


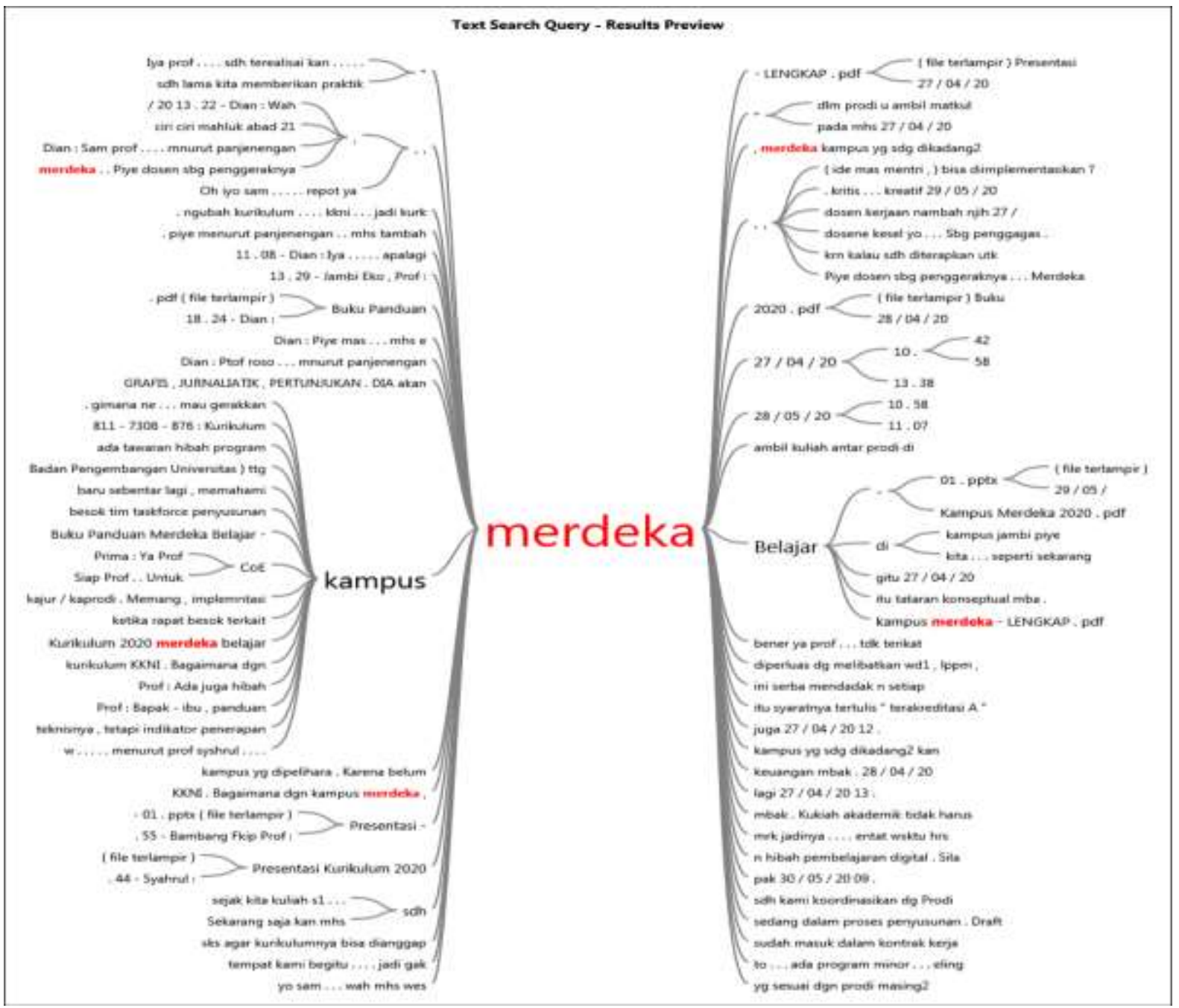

Figure 1: Tree Diagram of Subject Perception of Independent Campus

Based on Figure 1, it appears that in general all subjects have their own perceptions about independent campus, but the quality of the subject's understanding about the concept of an independent campus varies greatly. It is suspected that the concept of an independent campus is something "new", although actually it has been done by each subject. Likewise with a variety of other academic activities, subjects have the freedom to develop themselves significantly, so that independence affects their style of treating students. Thus the condition of the working atmosphere on campus is also felt to be influenced by it. This is shown in table 1 and realized in the tree diagram in figure 1.

The depiction of the subject's perception quality (figure 1 ), which was successfully explored through chat both individually and in groups, needs to be supplemented with a variety of data that was successfully collected in the form of text (Newspapers) written by the person concerned, video uploaded by the subject which was successfully recorded, and from various SE that successfully influenced the subject's behavior. This is necessary so that the subject will be able to change to get out of his comfort zone.

\section{CONCLUSION}

The conclusions intended in this study are; (1) the perception model of the subjects are the perception models that have been held since they served as lecturers. This perception model is very individual although its quality will develop with various inputs such as input from WAG, SE, guidebooks, articles published in online media, and videos. (2) Furthermore, the language style that used by the subjects was influenced by the cooperative maxims (Cooperative Principle), politeness with the typical mode of peer communication, and formal language. These style of language is conveyed in response to the speech partner's critically.

\section{REFERENCES}

[1] Anies Basweldan. (2018, Agustus) Karakteristik Manusia Abad 21.

[2] Ananto Kusumo Seto. (2017, Agustus) Kebutuhan Pembelajaran Abad 21di Sekolah, Apa yang Harus Dilakukan oleh LPTK "Refleksi 35 Tahun FKIP". 
[3] Joko Widodo. (2020, April) Pandemi Covid 2019.

[4] Ari Ambarwati. (2020, April) alif.id Berkeislaman dalam Kebudayaan. [Online]. https://alif.id/read/ariambarwati/interupsi-belajar-itu-bernama-pandemi$\underline{\mathrm{b} 227698 \mathrm{p} /}$

[5] Djoko Saryono. (2020, February) MERDEKA BERBAHASA DAN BERSASTRA UNTUK MERDEKA BELAJAR. Document.

[6] Djoko Sarnyono, Waras Kamdi dan Nur Mukminatin Ahmad Rofi'uddin, "Seri Kajian Inovasi Belajar Univeritas Negeri Malang, Menginovasi Pendidikan Tinggi, Kurikulum Transdisipliner dan Berbasis Kehidupan," Jakarta, 2017.

[7] Wahyu Adityo Prodjo. (2020, January) Kompas.com. [Online]. https://edukasi.kompas.com/read/2020/01/24/17032531/mendikbudnadiem-luncurkan-4-kebijakan-kampus-merdeka-inipenjelasannya?page=all

[8] Universitas Bengkulu. (2020, April) Conveying Better Future.

[9] Nafri Yanti, Susetyo Susetyo, Suhartono Suhartono Dian Eka Chandra Wardhana, "Student's Problem in Writing Results and Discussion Section of Research Articles for International Journals," in Proceedings of the International Conference on Educational Sciences and Teacher Profession (ICETeP 2018), Bengkulu, 2019, pp. 166-169.

[10] Dennis Yu Selina Griffin. (2020, June 10th - 11th 2020) QS Graduate Employability Rankings 2020.

[11] Djoko Sarnyono, Waras Kamdi, Sri Rahayu Ahmad Rofi'uddin, "Inovasi Belajar Responsi Budaya Lokal," Jakarta, 2017.

[12] Kompasiasa. (2011, July) Think Global Act Local.

[13] Engkus Kuswarno, Metode Penelitian Komunikasi: Etnografi Komunikasi. Bandung, Indonesia: Widya Padjadjaran, 2008.

[14] Bodhiya Wijaya Mulya Amelia Sidik, "Pendekatan Analisis Data Menggunakan Nvivo-Software untuk Penelitian Design Logo Museum Nasional Jakarta," Jurnal Desain Komunikasi Visual Nirmana, vol. 13, no. 1, pp. 1-4, January 2011.

[15] Yohanes Enggar Harususilo. (2020, January) Kompas.com. [Online]. https://edukasi.kompas.com/read/2020/01/25/11354331/inirangkuman-4-kebijakan-kampus-merdeka-mendikbudnadiem?page $=$ all 